\title{
A Mixed-Method Study of Programme Management Resources and Social Enterprise Sustainability: A Developing-Country Context
}

\author{
Arif ud Din ${ }^{1}$, Syed Mohsin Ali Shah ${ }^{1}{ }^{(}$, Hatem El-Gohary $\left.{ }^{2}{ }^{(}\right)$, Raza Ur Rahman ${ }^{1}$, Muhammad Haleem ${ }^{3, *(\mathbb{D},}$ \\ Muhammad Jehangir ${ }^{1}$, Syed Haider Khalil ${ }^{1}$ (D) and Sayyam ${ }^{1}$ \\ 1 Garden Campus, Institute of Business Studies and Leadership, Abdul Wali Khan University, \\ Mardan 23200, Pakistan; arif.hoti@gmail.com (A.u.D.); syedmohsinali@awkum.edu.pk (S.M.A.S.); \\ razaurrahman@awkum.edu.pk (R.U.R.); jehangir@awkum.edu.pk (M.J.); \\ haiderkhalil@awkum.edu.pk (S.H.K.); sayyam@awkum.edu.pk (S.) \\ 2 College of Business and Economics, Qatar University, Doha 2713, Qatar; helgohary@qu.edu.qa \\ 3 Department of Computer Science, Kardan University, Kabul 1003, Afghanistan \\ * Correspondence: m.haleem@kardan.edu.af
}

check for updates

Citation: Din, A.u.; Shah, S.M.A.; El-Gohary, H.; Ur Rahman, R.; Haleem, M.; Jehangir, M.; Khalil, S.H.; Sayyam A Mixed-Method Study of Programme Management Resources and Social Enterprise Sustainability: A Developing-Country Context. Sustainability 2022, 14, 114. https://doi.org/10.3390/su14010114 Academic Editor: Wen-Hsien Tsai

Received: 22 September 2021 Accepted: 15 November 2021 Published: 23 December 2021

Publisher's Note: MDPI stays neutral with regard to jurisdictional claims in published maps and institutional affiliations.

Copyright: () 2021 by the authors Licensee MDPI, Basel, Switzerland. This article is an open access article distributed under the terms and conditions of the Creative Commons Attribution (CC BY) license (https:// creativecommons.org/licenses/by/ $4.0 /)$.

\begin{abstract}
This research investigates the relationship between enterprise environmental factors (EEFs) and programme management $(\mathrm{PgM})$ resources, and subsequently how PgM resources and sustainability integrate into social enterprise. With a resource-based view (RBV) concept as the theoretical starting point, a systematic literature review identified EEFs relating to PgM resources, and PgM resources relating to sustainability in private and public organisations. A mixed-method research approach was used that is founded on a sequential exploratory strategy. In the preliminary phase, meta qualitative analysis was conducted; in the second phase, 16 semi structured interviews were undertaken to customise and confirm the concepts by using thematic analysis within 4 selected case studies. In the final phase, the model was validated by a survey that returned $(n=302)$ completed questionnaires from around Pakistan, and the used method of analysis was PLS-SEM. These research findings highlight that PgM resources within social enterprises are highly influential and dependent on external and internal EEFs, and that PgM resources are critical to consider for social enterprise sustainability. In addition, this study highlights that PgM resources positively influence social, economic, and environmental sustainability in SEs. Furthermore, this study developed a validated novel theoretical framework.
\end{abstract}

Keywords: sustainability; social enterprise; programme management resources; enterprise environmental factors; resource-based view; mixed-method; PLS-SEM; Pakistan

\section{Introduction}

Organisations are involved in social entrepreneurship because it can resolve climate change other societal issues such as hunger and illiteracy, and other hindrances to sustainability [1,2]. SE is a means for attaining sustainable development and a creative activity that generates societal value [3,4].

In addition, after Grameen Bank and its initiator, M. Yunus, won the Noble Prize in 2006, SE received significant attention [5]. However, governments globally are increasingly investigating the potential of social projects as an alternative service delivery vehicle [6]. Another study described how SE is an important source for the development or employment creation of disadvantaged communities [7].

SE is gaining popularity in Pakistan. There is also an increase in social investment, job creation, and poverty reduction programmes. Moreover, SE is perceived as a method of social and/or economic transformation, opening up growth and inclusion for Pakistan's developing economy [8]. The social enterprise ecosystem in Pakistan is young but rapidly 
growing. Social enterprises may also help Pakistan in achieving SDGs by providing feasible service delivery methods [9].

Project-management (PM; team and organisational) capabilities contribute to private organisations' competitive advantage [10-12]. Moreover, PM resources (such as teams, organisational resources, and collaborative and social resources) are important for nongovernmental organisations (NGOs) to improve their project performance [13]. In addition, the 6th edition of PMBOK changed the human resource management knowledge area to resource management, reflecting a positive role for portfolio, programmes, and initiatives to keep an eye on all tangible and intangible resources, and not only human resources [14].

Sustainability is a relatively new concept in the PM literature $[15,16]$. However, sustainability is an essential part of business strategy since it ensures the future of people, businesses, and the planet [17]. Similarly, other research found that the term "sustainability" is gaining popularity in the industrial and business worlds. The triple bottom line of business comprises three main variables: people, the planet, and money (three pillars) [18]. The process of identifying, preparing, monitoring, managing, and implementing programmes and projects ensures that established benefits are helping in building a sustainable society, and that sustainable programme management is well-defined [19].

Furthermore, a number of eminent academics concluded that incorporating sustainability necessitates a shift in PM from time, money, and efficiency to social, environmental, and economic effects $[15,20,21]$. It is also a paradigm shift from time, budget, and quality control (a degree of predictability and control) to sustainability integration [15]. One of the studies added that the most current programme and project management principles directly apply to sustainability as a factor to consider in programme and project management and governance [22].

However, the triple bottom line of sustainability must be integrated and implemented within project and programme management, and there is still a gap in the literature and practice [23-25]. Professionals and academics have attracted more exposure to sustainability [15]. However, it is still a challenge in PM development [26].

Many researchers discovered that social enterprises often face various problems when it comes to accessing scarce resources. These issues may impact the long-term viability of their operations [27-31]. In addition, there is a lack of evidence supporting various issues related to resource management in social entrepreneurship. This issue and the lack of knowledge on sustainable project management are factors that prevent people from creating a sustainable society [32-34].

Social entrepreneurship in Pakistan faces many challenges, such as inadequate institutional support, political and social unpredictability, and the absence of sufficient funds and support networks. This sector also has numerous educational and research issues $[8,9,35]$. Further, the main challenge facing social enterprises in Pakistan is the lack of resources and the sustainability of their operations [35].

This study mainly addresses this gap by identifying and investigating the relationship between enterprise environmental factors (EEFs) and programme management (PgM) resources, and how PgM resources and sustainability integrate into social enterprise in Pakistan. The study is based on RBV theory in social enterprise, and aims to draw relevant recommendations for its potential success and sustainability.

The main contribution leads to approaching sustainability in a programme management context, developing and validating a theoretical framework for examining PgM resources and their critical antecedents (EEFs), and exploring the relationships with programme sustainability in SEs. The methodological contribution is a mixed-method approach that is rarely used in exploring sustainability and PgM resources. In addition, context-specific PgM resources and their antecedents are explored with the lens of RBV. Earlier, traditional development approaches were used.

The rest of this article is arranged as follows: Section 2 provides an overview of the literature review and theoretical background, and Section 3 discusses the method that was 
used to conduct the research. Section 4 contains data analysis, and Section 5 presents the discussion, future implications, and conclusion.

\section{Literature Review}

Project management $(\mathrm{PM})$ is a newer field with little theoretical underpinning. Over the past decade, many studies utilised the resource-based perspective to demonstrate PM discipline as a means of achieving a sustainable competitive advantage [27,28]. According to the study, applying RBV to PM may help academics and professionals better understand how PM impacts strategy, and how PM creates a sustainable competitive advantage [29] (p. 23). RBV has been recognised as a prominent paradigm for understanding, demonstrating, and anticipating resource-based sustainable competitive advantage for two decades [30].

\subsection{Programme Management (PgM) Resources}

PgM resources are based on explicit and implicit intangible knowledge resources [31-33], also known as "know-what" and "know-how" [34]. In real-world business, knowledge is composed of both implicit and explicit components [35-37]. There is very little research that holistically examines project resources in SEs. Because PM necessitates critically looking at both knowledge-based resources to fully comprehend the elements of PM resources in SEs that enable the delivery of projects and programmes in challenging situations, PM resources are divided into three levels. Team PgM resources are specified within teams as explicit or implicit elements. Organisational PgM resources: organisational tools of PM include both explicit tools such as regulations, rules, and expectations, and implicit resources such as norms, principles, and routines [13,38,39], collaborative social PgM resources: as a shared social resource, research studies describe networking with partners, consortium meetings, formal and informal meetings, and joint visits [13].

Previous PM resource research established private-sector resource forms (both explicit and implicit) and two levels (team and organisational). Other research explored three different levels in Sri Lankan NGOs (team, organisational resources, and collaborative social resources). These resources are, however, not explored in social enterprises, and their relationship with sustainability and PgM resources and their antecedents have also not yet been studied.

\subsection{Sustainability and Project Management}

Some of the research concentrates on the incorporation of sustainability aspects into project management and implementation processes, such as stakeholder recognition and interaction [40,41], project procurement process [42], and business case development [43]. Several academics propose that project management should focus on social, environmental, and economic impact rather than time, budget, and quality $[15,21]$.

\subsection{Linking Sustainability and Social Enterprise}

Sustainability is expressly mentioned in the most recent project management principles as a point of view that should be considered in project management and governance [22]. Innovative project planning and execution methods that include sustainability positively impact the organisation's overall greening and environmental benefits [18]. There are two ways to look at the relationship between sustainability and PM: the project's sustainability outcome (deliverable) and process [44]. Using the triple-bottom-line views, the project's content-related aspects can be more sustainable, such as deliverable parameters and design [23,45] used materials [46], and desired outcomes [15,47]; simplifying sustainability into content-related issues might lead to more sustainable deliverability, but this approach risks ignoring a comprehensive strategy that incorporates triple-bottom-line aspects.

Social enterprises may generate helpful social improvements through creating ample surplus to withstand the market, thereby supplying public services with economic provision [48]. However, structural vicissitudes limit such enterprises' development and their ability to change environmental management practises [49]. Non-profit (such as 
social) organisations' activities, on the other hand, tend to be more parallel to sustainability and its methods, as one of their primary goals is to provide goods or services without monetary compensation [50]. Another study analysed ten distinct cases of non-profit social enterprises that concluded on the need to establish sustainable approaches from policies to operation level in projects [51]. The majority of research mainly focused on the environmental rather than the economic dimensions of sustainability, while very little research explored the social dimension [52]. Social sustainability is achieved by caring for and protecting people at all stages of business. It promotes the values of knowledge, admiration, diversity, vivacity, and obligation towards the workforce and community [52]. Environmental sustainability: The project itself and vendor efficiency are disputed. Supplier collaboration, in their opinion, aids project sustainability [15]. Selecting material processing for the project on the basis of energy consumption and/or emissions was proposed, integrated in product and logistic operations to achieve sustainability. Economic sustainability: The economic line of TBL refers to the organisation's effect on the economic system [53]. It concerns the economy's capacity to endure and develop in order to support future generations [54]. The economic line relates the organisation's development to the economy's growth and how effectively it supports it. In other words, it focuses on the organisation's economic worth to the surrounding system, promoting its prosperity and capacity to sustain future generations.

\subsection{Theoretical Point of Departure}

Project management is a relatively new discipline, a theoretical framework, and a broad theoretical foundation. Despite this, the resource-based view is considered to be the most widely studied theory in the management literature [55-58]. Several studies over the last decade used the resource-based perspective to demonstrate the PM discipline [36,37].

Applying RBV to PM can help academics and professionals in understanding the link between strategy and PM, and the characteristics of a PM that create competitive advantage [38]. In addition, intangible assets are those that can be used to achieve a competitive advantage [39].

RBV still considers its initial stage as a discipline of project management. While it is widely recognised and justified in the fields of strategic management and organisational development, there is a growing interest in applying the RBV approach [59]. Because PgM resources are intangible, and one of the major characteristics of competitive advantage is sustainability, RBV theory was used to investigate the relationship between numerous exogenous and endogenous factors in this study.

\subsection{Phase 1-Metaqualitative Analysis}

In order to establish and synthesise the present frame of information on EEFs and PgM resources for sustainable social enterprises, a qualitative meta-analysis method was used to compile relevant articles and professional criteria [60]. The keywords chosen to search the literature were enterprise environmental factors, social enterprise, external and internal factors, project management, programme management, project management tools, social enterprise sustainability, project management sustainability, sustainability, and sustainable development.

Appropriate publications were found in major databases, including Science Direct ${ }^{\circledR}$, EMERALD, Springer Link, Tayler and Francis Papers, and Google Scholar ${ }^{\circledR}$ by screening the title, abstract, and keywords. The abstract and introduction portions of the selected documents were then examined, and relevant objects were retained (fitting specifically with at least two of the keywords). In order to shape the basis for establishing the initial pool of EEFs and PgM tools for further refinement, more than 50 related publications, checklists, and standards were examined. 


\subsection{Research Framework}

Figure 1 depicts the recommended study framework based on the extensive literature review and exploratory analysis findings. PgM resource antecedents, PgM resources, and SE sustainability were developed in the research framework. The relationship of the elements discovered in the study framework is unique to SEs in developing countries.

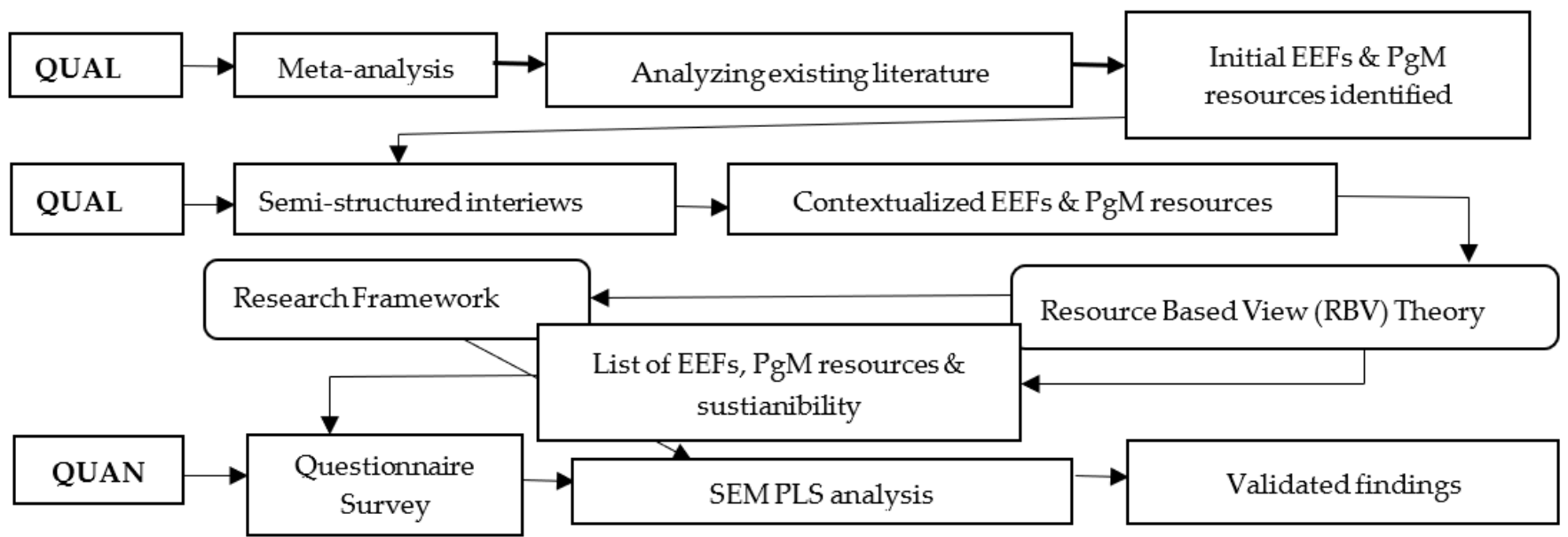

Figure 1. Mixed-method research design.

\section{Research Methods}

The main objectives of this research study are to uncover the EEFs that affect PgM resources in SEs programmes, and identify PgM resources and their influence on social enterprise programme sustainability. In management and organisational research, a mixed methodology is typically recognised as the most successful method. Figure 1 shows that, for this study, the Qual model followed a mixed-method methodology [61]. In addition, qualitative conceptual analysis was conducted to support and enrich the findings of the following quantitative approach, known as the sequential exploratory approach.

In the first phase, the qualitative step described and confirmed a contextualised list of critical external and internal enterprise environmental factors, and PgM resources in SEs. Targeted interviewees included practitioners with sufficient expertise in the management of social enterprises. In total, 30 programme management practitioners were contacted by phone and email, with 16 individuals agreeing to take part in the study, as indicated in Table 1 (interviewees and social enterprises). A rich variety of knowledge was considered to be representative of the study. All interview sessions with interviewees were properly recorded. According to the study, 15 interviews is the minimal appropriate sample size for qualitative research, and 16 interviews are an appropriate representative sample for this study [62].

The research model for the quantitative phase of the investigation was built on the results of the qualitative phase. The qualitative approach was dominant in this research, with the goal of identifying the PgM resources and their antecedents in social enterprise. A quantitative questionnaire survey was also undertaken in the next phase to generalise the results of the qualitative phase.

A convenient sampling technique was employed. Data were obtained using a Google Docs online questionnaire and a self-administered approach. In addition, the LinkedIn professional network was used to collect data online. Lastly, 317 completed questionnaire forms were obtained from social entrepreneurship programme employees across Pakistan. The 302 questionnaire forms were finalised after an initial screening process. 
Table 1. Case-study details.

\begin{tabular}{|c|c|c|c|c|c|}
\hline Case Study & Respondent ID & $\begin{array}{l}\text { Experience } \\
\text { (Years) }\end{array}$ & Role & Year of Estb. & $\begin{array}{c}\text { Nature of } \\
\text { Programme }\end{array}$ \\
\hline \multirow{4}{*}{ Case 1} & 1 & 8 & Programme manager & \multirow{4}{*}{1990} & \multirow{4}{*}{$\begin{array}{l}\text { Edu, health, } \\
\text { and microfinance }\end{array}$} \\
\hline & 2 & 15 & Manager programmes & & \\
\hline & 3 & 23 & President & & \\
\hline & 4 & 19 & $\mathrm{M}$ and $\mathrm{E}$ manager & & \\
\hline \multirow{4}{*}{ Case 2} & 5 & 15 & Programme manager & & \multirow{4}{*}{$\begin{array}{c}\text { Livelihood, edu, } \\
\text { tourism }\end{array}$} \\
\hline & 6 & 12 & Senior programme officer & & \\
\hline & 7 & 5 & Programme development officer & 1998 & \\
\hline & 8 & 6 & $\begin{array}{l}\text { Senior marketing and } \\
\text { communication officer }\end{array}$ & & \\
\hline \multirow{4}{*}{ Case 3} & 9 & 13 & Project manager & \multirow{4}{*}{2005} & \multirow{4}{*}{ Education } \\
\hline & 10 & 6 & Project manager & & \\
\hline & 11 & 9 & Project manager & & \\
\hline & 12 & 9 & Academic & & \\
\hline \multirow{4}{*}{ Case 4} & 13 & 15 & Head of programmes & \multirow{4}{*}{1994} & \multirow{4}{*}{ Education } \\
\hline & 14 & 12 & Programme manager & & \\
\hline & 15 & 16 & Programme coordinator & & \\
\hline & 16 & 23 & Programme manager, $\mathrm{M}$ and $\mathrm{E}$ & & \\
\hline
\end{tabular}

\subsection{Phase 2-Semistructured Interviews}

This phase entailed conducting semi structured interviews with four social enterprise senior programme management professionals to contextualise the preliminary list of established EEFs and PgM services from phase 1 in the setting of developing countries. As a supporting text, the organisational archive was also checked. The researchers used an exploratory case study that is generally suggested to richly investigate the essence of topics from different sources of evidence [63]. A minimum of two cases were used in the most comparable setting [64]. PgM resources and their antecedents were not discussed in SEs; therefore, the case study is a helpful method for exploring the concepts. Second, the case study assists in establishing the study's theories and conceptual model $[65,66]$. Furthermore, semi structured interviews are useful for clarifying or gathering new information, whereas archival data may be used to confirm or support interview material [65].

\subsection{Phase 3 (PLS-SEM)}

The study's developed hypotheses were tested using a structured questionnaire. There are three sections to the questionnaire. The goals of the research study, and definitions of important topics and the demographics portion of the study, were included in the first section. The EEFs and PgM resources verified as a result of the qualitative stage were part of the second section, and sustainability factors were added in the third section. $\mathrm{PgM}$ resources and social enterprise sustainability factors were measured using a 7-point Likert scale, while EEFs factors and their items were measured using a 5-point Likert scale.

When a study's hypothesis is to look into the relationships among variables and the strength of those relationships, multivariate regression is an acceptable data analysis method [67]. The most appropriate strategy for data analysis is determined by the study's aims and the nature of the collected data. PLS-SEM was chosen as the most suitable as advised due to the trivial sample size, the originality of the theoretical model, and capacity for analysing models centred on examination and estimating connections among a variety of dimensions [68]. PLS-SEM was utilised to analyse the data. 


\section{Result and Discussion}

\subsection{Contextualised List of EEFs (Antecedents of PgM Resources) (Semistructured Interviews)}

A comprehensive semi structured interview guideline was first presented to the chosen interviewees a week before to better understand and provide useful input during the interview in order to help the interviewees gain an accurate understanding of the definition. This was to ensure that all participants had a thorough understanding of the research subject and that their understanding of the terms, definitions, and criteria was the same. Interviewees were given a list of EEFs and PgM resources, and instructed to think aloud about the items. They were given three options for expressing their opinions on an item: agreement, disagreement, or extensive change advice; add, eliminate, or combine. The list was changed because of this procedure. The external EEFs of the "social forces" and "cultural effects" social enterprises' commercial databases and the external political environment were excluded. Most of the respondents agreed that the execution of our programme is within the country; thus, programme resources are rarely affected by the external political environment. In addition, respondents added that their organisations have no formal relations with research institutes and universities, and that commercial databases are available that do not impact PgM resources in non-profit SEs.

Internal EEFs, internal policies, information technology, and the internal political environment of social enterprises were excluded because programme experts indicated that the exclusion of this element is rational in the context of Pakistan. Most of the respondents indicated that the politics of internal organisations, internal policies, and information technology have a lesser effect on PgM resources, and are perceived to be less critical of the non-profit SE's internal EEF. As a result, a 38-item list of EEFs was finalised as a personalised list of EEFs for developing countries. Next, the research model of the study was presented to interviewees, as demonstrated in Figure 2, and they were asked to allocate each of the EEFs to the final model list. The process allocated to each EEF was decided by the majority of the respondents. tables 2 and 3 classify the discovered external and internal aspects of PgM resources, along with the measuring indicators that were used to determine their significance.

Table 2. Classification of antecedents of external EEFs.

\begin{tabular}{|c|c|}
\hline Factors & Indicators \\
\hline \multirow{5}{*}{ Financial consideration } & Inflation \\
\hline & Increase in interest rate \\
\hline & Geographical location of the resource \\
\hline & Currency exchange rate \\
\hline & Governmental rules and regulations \\
\hline \multirow{3}{*}{ Legal restriction } & Country policy \\
\hline & Security situation \\
\hline & Political environment \\
\hline \multirow{4}{*}{ Marketplace condition } & Employment and procurement laws \\
\hline & Local competitors \\
\hline & Donors \\
\hline & Organisation trademark \\
\hline \multirow{4}{*}{ Social and cultural influences } & Country political environment \\
\hline & Local values \\
\hline & Local perception \\
\hline & Local culture \\
\hline \multirow{4}{*}{ Physical environmental elements } & Extreme weather conditions \\
\hline & Natural disasters \\
\hline & Climate change \\
\hline & Remote area working condition \\
\hline
\end{tabular}


Table 3. Classification of antecedents of internal EEFs.

\begin{tabular}{cc}
\hline Factors & Indicators \\
\hline & Expertise \\
Employee capability & Experience \\
& Competence \\
Organisation structure & Knowledge \\
& Hierarchy and authority \\
& Leadership style \\
& Formal and informal communication channel \\
& Decision making \\
Resource availability & Human resource \\
& Supplies \\
& Material \\
& Equipment \\
Organisational culture & Facilities \\
& Vision \\
& Mission \\
& Beliefs \\
& Values \\
\hline
\end{tabular}

\begin{tabular}{|c|c|c|}
\hline $\begin{array}{l}\text { Antecedents of PgM } \\
\text { Resources }\end{array}$ & PgM Resources & $\begin{array}{l}\text { Sustainability of Social } \\
\text { enterprise }\end{array}$ \\
\hline
\end{tabular}

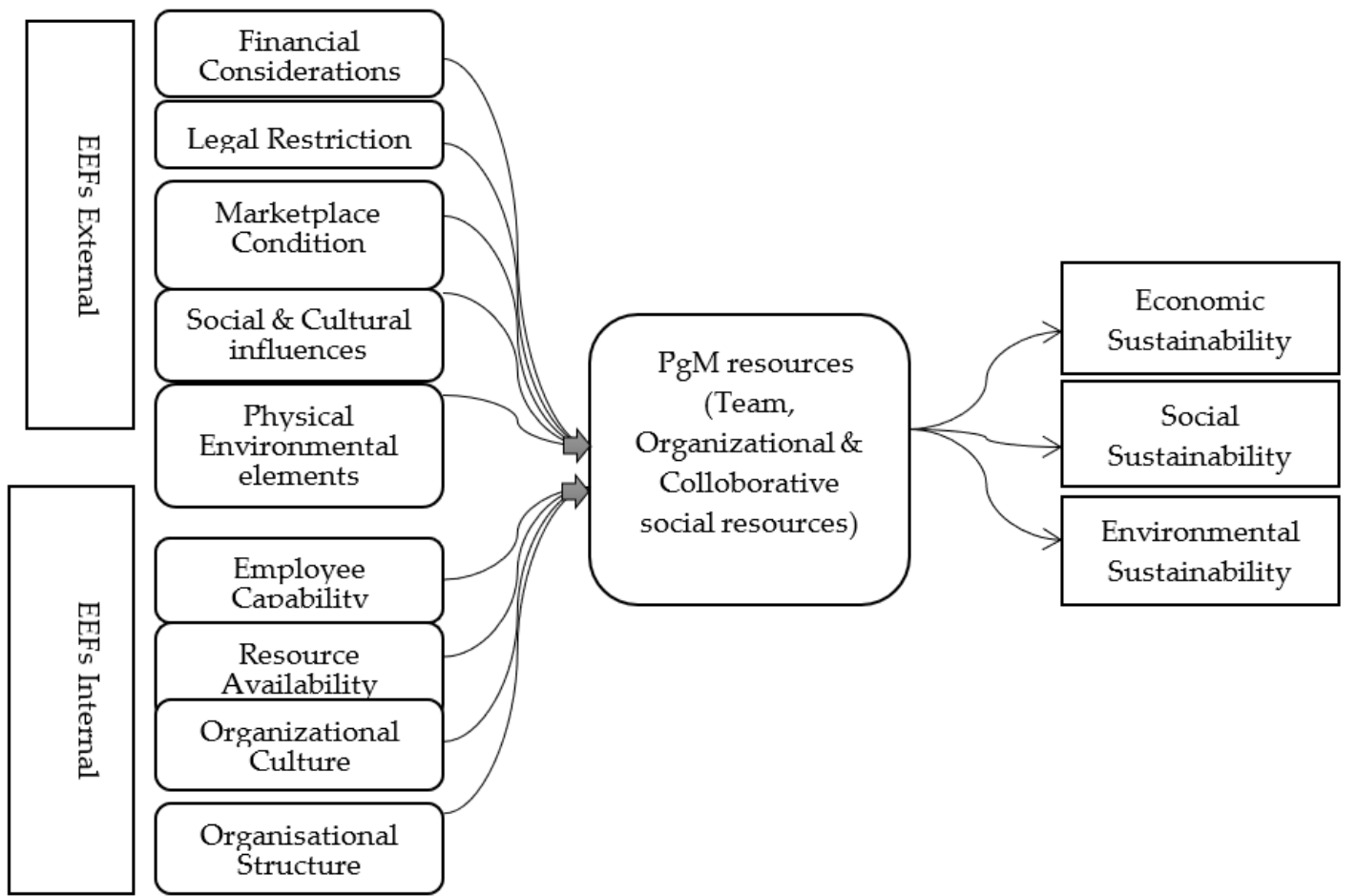

Figure 2. Theoretical framework.

Figure 2 illustrates the road map of the mixed-method research (sequential exploratory design).

\subsection{Contextualised List of PgM Resources in SEs (Semistructured Interviews)}

Through the RBV lens, the case study examined and validated PgM elements and resources. However, processes evaluated at the team and organisational levels, and those analysed outside the organisation are collaborative social PgM resources. PgM resources are analysed in relation to explicit and implicit understandings. 
Thirteen Team PgM resources were discovered in the SE programme according to the case study. Furthermore, the findings of this study support and contextualise previous research findings, and identify additional team resources in program-based organisations, such as team expertise, team personal relationships, team issue resolution, and team planning ability.

In addition, the exploratory case study in a social business revealed twelve organisations' PgM resources. The majority of identified PgM resources are comparable to those available in NGOs and the commercial sector. This study, on the other hand, found these resources in extremely sophisticated social entrepreneurship programmes. Furthermore, organisational HR procedure and technique, and organisational image, are unknown resources in PM research.

Eleven collaborative social PgM resources exist in social businesses, according to the exploratory case study. Furthermore, the case study exposed that team PgM resources are organic power that cannot be codified or transferred. PgM resources, on the other hand, are written and transferable public capacities within organisations. The findings of the case study showed that team resources are tacit; nevertheless, organisational resources (explicit and tacit) encourage the production of PgM resources, and collaborative social resources primarily connect SE with external stakeholders. It also supports findings that all forms of evidence are extensively employed to facilitate the attainment of specialised knowledge [55]. The confirmed lists of PgM resources, which consist of 36 items in nonprofit social businesses in the setting of Pakistan, are presented in Table 4 below.

Table 4. Classification of PgM resources.

\begin{tabular}{|c|c|}
\hline PgM Resources & Indicators \\
\hline Team PgM resource & $\begin{array}{c}\text { Casual discussion and informal gathering } \\
\text { Brainstorming } \\
\text { Field trips } \\
\text { On-job preparations } \\
\text { Successes and failures case studies } \\
\text { Cohesion and trust } \\
\text { Job shadowing and mentoring } \\
\text { Team beliefs } \\
\text { Best PgM Practices } \\
\text { PgM expertise } \\
\text { Team PgM experience } \\
\text { Planning and problem-solving capability } \\
\text { Team contacts }\end{array}$ \\
\hline Organisational PgM resource & $\begin{array}{c}\text { PgM office } \\
\text { PgM methodology, standards, and process } \\
\text { PgM tools and techniques } \\
\text { PgM information system } \\
\text { Programme, M and E } \\
\text { Programme workforce capacity development } \\
\text { Formal sharing knowledge meeting } \\
\text { Programme communication } \\
\text { Org. culture to PgM } \\
\text { Org. leadership to PgM } \\
\text { Org. HR practices } \\
\text { Org. image }\end{array}$ \\
\hline $\begin{array}{c}\text { Collaborative Social PgM } \\
\text { Resource }\end{array}$ & $\begin{array}{c}\text { Programme advice from government } \\
\text { Programme advice from donors } \\
\text { Consortium summits } \\
\text { Official Info dissemination } \\
\text { Joint programme formal relation } \\
\text { Joint programme informal relation } \\
\text { Stakeholder interaction } \\
\text { Beneficiary integration in programme } \\
\text { Programme social marketing } \\
\text { Online networking (community practice) } \\
\text { Community-level advocacy }\end{array}$ \\
\hline
\end{tabular}




\subsection{PLS-SEM Results}

According to the research, a two-stage analytical approach was used, with the measurement model first investigated; then, the structural model was evaluated [68]. As a result, the expectation-maximisation (EM) method was adopted for missing-value imputation in the current study [56]. Furthermore, age, gender, and education were control factors in this study.

The first-order factor measurement model was first examined, followed by a second (higher-order) factor measurement model. All first-order constructs were evaluated using the assessment criteria for evaluating reflective measurement models. In addition, some measures were used to evaluate the first-measurement order's model. These measures were internal consistency, convergent validity, and discriminant validity (DV) [57]. The internal consistency of constructs was then assessed using composite reliability (CR) (DillonGoldstein rho) to determine the items' dependability (values ranging between 0 and 1). Only if the result exceeds 0.7 does CR imply good internal consistency [58]. Following that, all reflective indicator loadings greater than 0.7 in the PLS model indicated acceptable convergent validity and were therefore kept.

If the construct's AVE did not exceed 0.5, entries producing values less than this were eliminated. As a result, four indicators were removed (i.e., LR5, FC4, RA1, and ECS1). All latent variables in the tested model had acceptable convergent reliability, as measured by AVE values greater than $0.5[56,69]$. A multitrait-multimethod matrix, also known as the heterotrait-monotrait (HTMT) ratio of correlations, was proposed as an alternative for DV [70]. As a result, in order to pass the DV test, all HTMT values must be less than 0.85 [71] or 0.90 [72]. Results passed both the basic criterion and the discriminant validity tests. Table 5 summarises all findings in detail. For the multicollinearity issue, the VIF value of PgM resources was evaluated before analysing the structural model, and all fell well within the permitted VIF of 3-5 [73]. Further, bootstrapping was conducted on the model using 5000 subsamples for the higher-order construct, resulting in a lower threshold of 0.649 and a greater threshold of 0.799 for the $95 \%$ confidence interval [74]. As the path coefficient did not significantly diverge from the 0.7 cut-off point, such a result confirms the higher-order constructs' convergent validity [57]. Table 6 shows that all of the significant weights $(p<0.05)$. The validity of the reflective-reflective higher-order construct is clearly supported by these findings.

Table 5. Internal consistency, reliability, and convergent validity.

\begin{tabular}{|c|c|c|c|c|c|c|}
\hline Constructs & Items & Loadings & $\begin{array}{c}\text { Cronbach's } \\
\text { Alpha }\end{array}$ & Rho A & $\begin{array}{l}\text { Composite } \\
\text { Reliability } \\
\text { (CR) }\end{array}$ & $\begin{array}{c}\text { Average } \\
\text { Variance } \\
\text { Extracted (AVE) }\end{array}$ \\
\hline \multirow[t]{3}{*}{ Marketplace condition } & mp1 & 0.917 & 0.928 & 0.929 & 0.928 & 0.811 \\
\hline & $\mathrm{mp} 2$ & 0.860 & & & & \\
\hline & mp3 & 0.923 & & & & \\
\hline \multirow[t]{4}{*}{ Legal restriction } & Lr1 & 0.875 & 0.947 & 0.948 & 0.947 & 0.818 \\
\hline & Lr2 & 0.930 & & & & \\
\hline & Lr3 & 0.906 & & & & \\
\hline & Lr4 & 0.907 & & & & \\
\hline \multirow[t]{4}{*}{ Social and cultural issues } & sc1 & 0.856 & 0.944 & 0.945 & 0.944 & 0.808 \\
\hline & $\mathrm{sc} 2$ & 0.878 & & & & \\
\hline & sc3 & 0.944 & & & & \\
\hline & sc4 & 0.915 & & & & \\
\hline \multirow[t]{4}{*}{ Physical environment } & pe1 & 0.873 & 0.948 & 0.949 & 0.948 & 0.821 \\
\hline & pe2 & 0.925 & & & & \\
\hline & pe3 & 0.923 & & & & \\
\hline & pe4 & 0.903 & & & & \\
\hline \multirow[t]{3}{*}{ Financial consideration } & $\mathrm{fc} 1$ & 0.913 & 0.916 & 0.917 & 0.916 & 0.785 \\
\hline & fc2 2 & 0.862 & & & & \\
\hline & fc3 & 0.883 & & & & \\
\hline
\end{tabular}


Table 5. Cont.

\begin{tabular}{|c|c|c|c|c|c|c|}
\hline Constructs & Items & Loadings & $\begin{array}{c}\text { Cronbach's } \\
\text { Alpha }\end{array}$ & Rho A & $\begin{array}{l}\text { Composite } \\
\text { Reliability } \\
\text { (CR) }\end{array}$ & $\begin{array}{c}\text { Average } \\
\text { Variance } \\
\text { Extracted (AVE) }\end{array}$ \\
\hline \multirow[t]{4}{*}{ Organisational culture } & o1 & 0.917 & 0.944 & 0.944 & 0.944 & 0.808 \\
\hline & $\mathrm{o} 2$ & 0.891 & & & & \\
\hline & o3 & 0.893 & & & & \\
\hline & $\mathrm{o} 4$ & 0.894 & & & & \\
\hline \multirow[t]{5}{*}{ Employee capability } & e1 & 0.891 & 0.943 & 0.944 & 0.943 & 0.769 \\
\hline & $\mathrm{e} 2$ & 0.857 & & & & \\
\hline & e3 & 0.828 & & & & \\
\hline & $\mathrm{e} 4$ & 0.909 & & & & \\
\hline & e5 & 0.896 & & & & \\
\hline \multirow[t]{4}{*}{ Organisational structure } & os1 & 0.943 & 0.944 & 0.945 & 0.945 & 0.810 \\
\hline & os2 & 0.892 & & & & \\
\hline & os3 & 0.882 & & & & \\
\hline & os4 & 0.880 & & & & \\
\hline \multirow[t]{3}{*}{ Resource availability } & $\mathrm{ra} 2$ & 0.935 & 0.932 & 0.933 & 0.933 & 0.822 \\
\hline & ra3 & 0.891 & & & & \\
\hline & $\mathrm{ra} 4$ & 0.894 & & & & \\
\hline \multirow[t]{11}{*}{ Team PgM resources } & $\mathrm{t} 1$ & 0.795 & 0.945 & 0.946 & 0.945 & 0.612 \\
\hline & t2 & 0.793 & & & & \\
\hline & $\mathrm{t} 3$ & 0.800 & & & & \\
\hline & $\mathrm{t} 4$ & 0.763 & & & & \\
\hline & $\mathrm{t} 5$ & 0.733 & & & & \\
\hline & t6 & 0.766 & & & & \\
\hline & $\mathrm{t} 7$ & 0.760 & & & & \\
\hline & t8 & 0.800 & & & & \\
\hline & t9 & 0.805 & & & & \\
\hline & $\mathrm{t} 10$ & 0.795 & & & & \\
\hline & $\mathrm{t} 11$ & 0.791 & & & & \\
\hline \multirow[t]{10}{*}{ Social PgM resources } & s1 & 0.776 & 0.939 & 0.939 & 0.939 & 0.607 \\
\hline & s2 & 0.760 & & & & \\
\hline & s3 & 0.768 & & & & \\
\hline & $\mathrm{s} 4$ & 0.777 & & & & \\
\hline & s5 & 0.784 & & & & \\
\hline & s6 & 0.792 & & & & \\
\hline & s7 & 0.773 & & & & \\
\hline & s8 & 0.787 & & & & \\
\hline & s9 & 0.790 & & & & \\
\hline & s10 & 0.782 & & & & \\
\hline \multirow[t]{11}{*}{ Organisational PgM resources } & or1 & 0.791 & 0.947 & 0.947 & 0.947 & 0.619 \\
\hline & or2 & 0.770 & & & & \\
\hline & or3 & 0.821 & & & & \\
\hline & or4 & 0.803 & & & & \\
\hline & or5 & 0.762 & & & & \\
\hline & or6 & 0.765 & & & & \\
\hline & or7 & 0.770 & & & & \\
\hline & or8 & 0.810 & & & & \\
\hline & or9 & 0.798 & & & & \\
\hline & or10 & 0.774 & & & & \\
\hline & or11 & 0.790 & & & & \\
\hline \multirow[t]{5}{*}{ Environmental sustainability } & ENS1 & 0.885 & 0.936 & 0.936 & 0.936 & 0.746 \\
\hline & ENS2 & 0.860 & & & & \\
\hline & ENS3 & 0.853 & & & & \\
\hline & ENS4 & 0.846 & & & & \\
\hline & ENS5 & 0.874 & & & & \\
\hline \multirow[t]{4}{*}{ Economic sustainability } & ECS2 & 0.841 & 0.923 & 0.924 & 0.923 & 0.750 \\
\hline & ECS3 & 0.855 & & & & \\
\hline & ECS4 & 0.888 & & & & \\
\hline & ECS5 & 0.880 & & & & \\
\hline \multirow[t]{5}{*}{ Social sustainability } & S1 & 0.860 & 0.934 & 0.934 & 0.934 & 0.738 \\
\hline & $\mathrm{S} 2$ & 0.863 & & & & \\
\hline & S3 & 0.829 & & & & \\
\hline & S4 & 0.853 & & & & \\
\hline & S5 & 0.887 & & & & \\
\hline
\end{tabular}

Note: LR5, FC4, RA1, and ECS1 were deleted due to low loading. CR, composite reliability; AVE, average variance extracted. 
Table 6. Loadings, reliability, and validity statistics of HOC.

\begin{tabular}{ccccccc}
\hline Constructs & Items & Weights & VIF & t Value & CI LL & CI UL \\
\hline Programme management resource & Org PgM R sources & 0.316 & 3.084 & 6.435 & 0.211 & 0.403 \\
& Social PgM Resources & 0.277 & 3.109 & 5.670 & 0.185 & 0.380 \\
& Team PgM Resources & 0.488 & 3.173 & 9.635 & 0.396 & 0.597 \\
\hline
\end{tabular}

$* p<0.05$ (two-tailed), ${ }^{* *} p<0.01$.

\subsection{Structural Model Assessment}

The two-phase model was used to conduct bootstrapping with 5000 resamples to test the hypothesis in Figure 3. The study supported all hypothesised associations, as shown in Table 7 (H1, H2, H3, H4, H5, H6, H7, H8, H9, H10, H11, and H12). All hypothesised associations indicated statistically significant results [74].

Table 7 shows that PgM resources have a weak influence on internal and external enterprise environmental factors, whereas PgM resources have a strong effect on economic, environmental, and collaborative social resources.

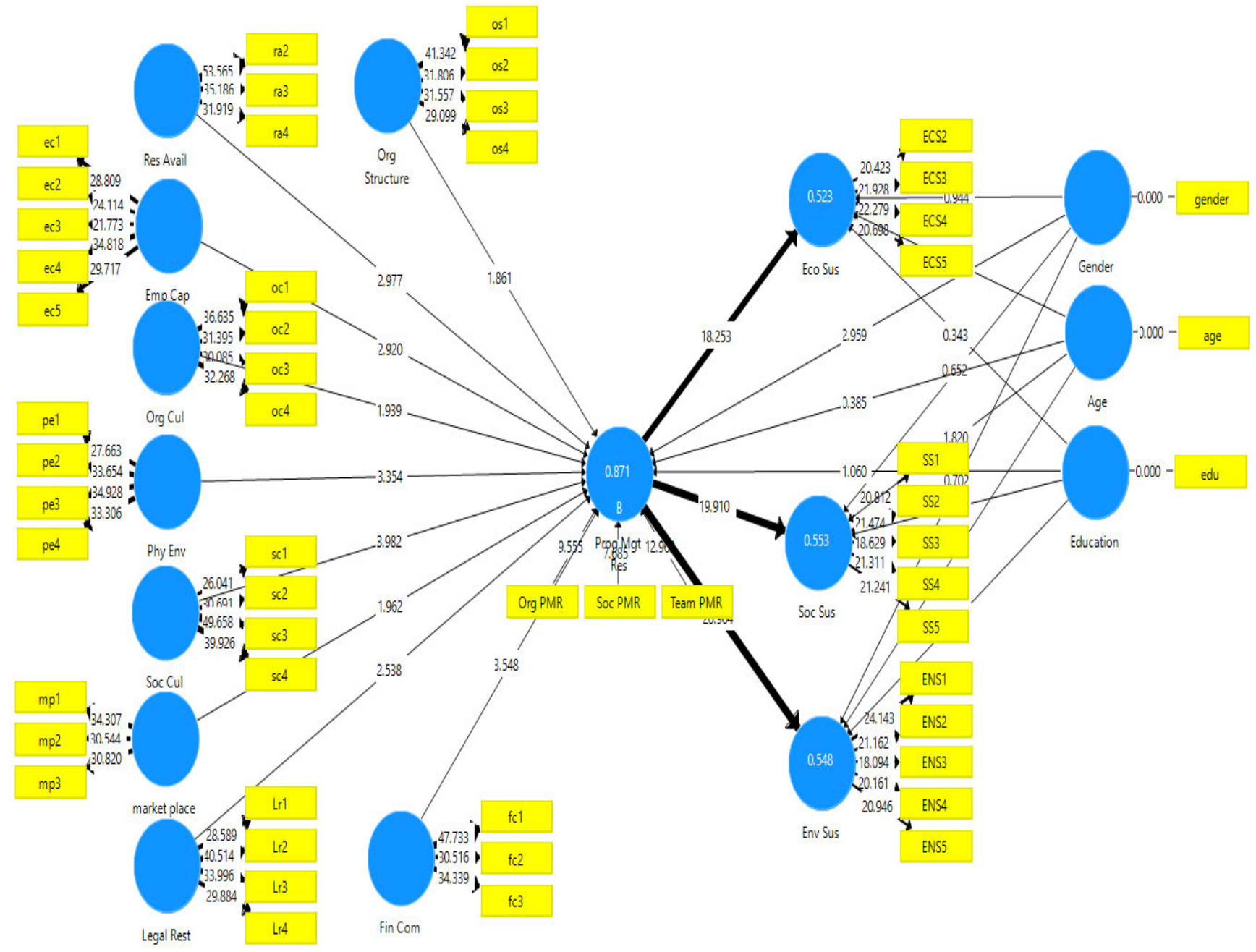

Figure 3. PLS-SEM structural analysis. R2 (Economic sustainability $=0.615$, colloborative social sustainability $=0.189$, environmental sustainability $=0.455)$. 
Table 7. Summary of effects.

\begin{tabular}{|c|c|c|c|c|c|c|c|c|c|}
\hline Hypothesis & Relationship & $\begin{array}{l}\text { Std. } \\
\text { Beta }\end{array}$ & $\begin{array}{l}\text { Std. } \\
\text { Error }\end{array}$ & t-Value & Decision & f2 & $p$-Value & $\begin{array}{l}95 \% \text { CI } \\
\text { LL }\end{array}$ & $\begin{array}{c}95 \% \text { CI } \\
\text { UL }\end{array}$ \\
\hline $\mathrm{H} 1$ & $\begin{array}{c}\text { Marketplace condition > PgM } \\
\text { Resource }\end{array}$ & 0.088 & 0.036 & 2.497 & Supported & 0.028 & 0.007 & 0.019 & 0.16 \\
\hline $\mathrm{H} 2$ & Legal Restriction > PgM Resource & 0.111 & 0.04 & 2.889 & Supported & 0.053 & 0.021 & 0.032 & 0.189 \\
\hline H3 & $\begin{array}{c}\text { Social and Culture issues > PgM } \\
\text { Resource }\end{array}$ & 0.171 & 0.037 & 4.606 & Supported & 0.108 & 0.041 & 0.101 & 0.246 \\
\hline $\mathrm{H} 4$ & $\begin{array}{c}\text { Physical Environment } \\
\text { elements }>\text { PgM Resource }\end{array}$ & 0.144 & 0.038 & 3.775 & Supported & 0.064 & 0.024 & 0.069 & 0.219 \\
\hline H5 & $\begin{array}{c}\text { Financial Consideration }>\text { PgM } \\
\text { Resource }\end{array}$ & 0.178 & 0.043 & 4.105 & Supported & 0.095 & 0.034 & 0.094 & 0.266 \\
\hline H6 & $\begin{array}{c}\text { Organisational Culture }>\text { PgM } \\
\text { Resource }\end{array}$ & 0.107 & 0.041 & 2.592 & Supported & 0.031 & 0.010 & 0.027 & 0.188 \\
\hline H7 & $\begin{array}{c}\text { Employee Capability > PgM } \\
\text { Resources }\end{array}$ & 0.15 & 0.04 & 3.706 & Supported & 0.062 & 0.014 & 0.075 & 0.233 \\
\hline H8 & $\begin{array}{c}\text { Organisational Structure }>\text { PgM } \\
\text { Resources }\end{array}$ & 0.101 & 0.043 & 2.323 & Supported & 0.031 & 0.010 & 0.019 & 0.188 \\
\hline H9 & $\begin{array}{c}\text { Resource Availability > PgM } \\
\text { Resources }\end{array}$ & 0.14 & 0.04 & 3.527 & Supported & 0.065 & 0.027 & 0.064 & 0.222 \\
\hline H10 & $\begin{array}{c}\text { PgM Resources > Environmental } \\
\text { Sustainability }\end{array}$ & 0.729 & 0.036 & 20.401 & Supported & & & 0.655 & 0.796 \\
\hline H11 & $\begin{array}{c}\text { PgM Resources > Economic } \\
\text { Sustainability }\end{array}$ & 0.703 & 0.038 & 18.318 & Supported & & & 0.625 & 0.775 \\
\hline $\mathrm{H} 12$ & $\begin{array}{c}\text { PgM Resources > Social } \\
\text { Sustainability }\end{array}$ & 0.721 & 0.036 & 19.904 & Supported & & & 0.648 & 0.789 \\
\hline
\end{tabular}

${ }^{*} p<0.05$ (two-tailed), ${ }^{* *} p<0.01$.

\section{Discussion}

Results from Smart PLS provide multiple configurations of conditions that lead to the confirmation that EEFs influence programme management resources and, subsequently, $\mathrm{PgM}$ resources affect social enterprise sustainability. On the basis of [12,13], this research analyses the importance of PgM resources. We find team, organisational and collaborative social resources in the programme management of Pakistani social enterprises. We also found the importance of enterprise environmental factors as antecedents of programme management resources. All of the research hypotheses can be validated using the gathered data. Our interviews showed that both external and internal enterprise environmental factors have some elements and items that are more appropriate and specific to the social enterprise's practical needs, as demonstrated by the interviewed programme management staff. In addition, the interviews looked into which PgM resource categories (team, organisational, and collaborative social resources) are more important than the tangible programme management resources used in the non-profit sector. This PgM resource finding is similar to that in NGO projects [13]. However, some items were added and some omitted. Overall, this research emphasises the complexities of programme management in social enterprises by deepening the knowledge of key aspects that might contribute to better performance. Although project management approaches and tools are crucial, we give both a qualitative and quantitative study that shows that different combinations of these features lead to diverse outcomes.

PLS SEM results support Hypotheses H1, H2, H3, and H4 that PgM resources significantly impact market conditions ( std beta $=0.088, \mathrm{t}$ value $=2.497, p$ value $=0.007$ ), legal restrictions ( std beta $=0.111, \mathrm{t}$ value $=2.889, p$ value $=0.021$ ), social and cultural influences $($ std Beta $=0.171, \mathrm{t}$-value $=4.606, p$ value $=0.041)$, physical environmental elements $(\mathrm{std}$ Beta $=0.144, \mathrm{t}$-value $=3.775, p$ value $=0.024)$, and financial considerations $($ std Beta $=0.178$, $\mathrm{t}$-value $=4.105, p$ value $=0.034)$ in SEs of Pakistan. The findings of the research survey indicated the significance of four external antecedents of PgM resources (EEFs) that significantly impact PgM resources in social enterprise. By verifying the linkages in the setting of SEs in Pakistan, this work advances the antecedents of PgM resource (EEFs) and its association. The PLS SEM also supports hypotheses H6, H7, H8, and H9, which are related to PgM resources and are influenced by organisational culture $(\operatorname{std} B e t a=0.107, \mathrm{t}$ value $=2.592$, 
$p$ value $=0.01)$, employee capability (std Beta $=0.15, \mathrm{t}$-value $=3.706, p$ value $=0.01)$, organisational structure (std Beta $=0.101$, $\mathrm{t}$-value $=2.323, p$ value $=0.01)$, and resource availability (std Beta $=0.14, \mathrm{t}$-value $=3.527, p$ value $=0.02)$, in SEs. The results of the survey study show the importance of the four internal antecedents of PgM resources (EEFs), which impact PgM resources in social enterprises.

The current study's PLS SEM results back up Hypotheses H10, H11, and H12, which claim that PgM resources significantly impact environmental sus. (std Beta $=0.729$, $\mathrm{t}$ value $=20.401, p<0.05)$, economic sus. $($ std Beta $=0.703, \mathrm{t}$-value $=18.318, p<0.05)$, and social sus. ( std Beta $=0.721$, $\mathrm{t}$-value $=19.904, p<0.05)$. However, when discussing the study's main hypotheses, all of our hypotheses were supported by the quantitative study's findings, implying that PgM resources within Pakistani SEs significantly impact their sustainability, and PgM resources are influenced by both external and internal antecedents.

\section{Conclusions, Limitations and Implications}

\subsection{Conclusions}

The RBV is increasingly being used to describe corporate operations since it provides a flexible foundation for developing theories [75]. This research focused on intangible resources that are associated with PgM activities in SEs and highlighted the importance of assessing PM capacity using the RBV. In the PM literature, intangibles are often promoted as a competitive advantage and have not been the focus [76]. However, in a recent study, the PM capability was discussed in relation to project success [13]. Programme management resources can enhance the sustainability of social enterprises in Pakistan. Similarly, in the present study, results and findings suggest that the social enterprises of Pakistan can improve the success and sustainability rates of their projects and programmes by directing their attention to the antecedents, both external and internal, influencing programme management resources, and by focusing on intangible programme management resources (team, organisational, and collaborative social). In the context of Pakistan, findings give fresh insights into the incorporation of sustainability into programme management practises. These perspectives reveal the most crucial factors to consider in order to ensure the long-term viability of a social company. Despite the deep concerns of many organisations about developing traditional organisational capacities such as building effective structures and human resource development, many still believe that these are very important to achieving success [77]. In practise, the study's findings give suggestions for policymakers and directors of social companies in developing nations. In other words, on the basis of the conclusions of this study, they could identify the most critical resources and how to enhance these resources in order to focus their efforts and allocate resources efficiently to achieve sustainability.

\subsection{Limitations}

Despite this study's mixed-method approach, the development of additional studies to better understand this phenomenon may be of significant importance.

Demographics of the study of social enterprises (e.g., experience, age, and education) that could be deepened. Second, because the data was obtained exclusively from non-profit social companies in Pakistan, further research could determine whether similar findings hold true in other countries with distinct economic, institutional, and cultural contexts. Finally, while each non-profit SE self-reported its sustainability, another route to investigate would be the stakeholders' viewpoint on non-profit social enterprise sustainability through interviews and survey data from private and public donors, suppliers, and communities.

\subsection{Implications}

The study is beneficial to social business managers because it delivers an improved knowledge of the factors affecting their long-term sustainability. It enables managers to rethink their strategy by putting more emphasis on PgM resources as well as internal and external EEFs. This study is important for policymakers since it examines PgM resources 
that contribute to social enterprise sustainability, such as when reviewing funding proposals. Finally, for academics, this study adds to their understanding of social entrepreneurship programme management processes.

Author Contributions: Conceptualisation, A.u.D., H.E.-G. and M.J.; methodology M.J. and H.E.-G.; software, S.M.A.S. and S.H.K.; validation, S.; Data analysis, S.H.K. and S.M.A.S.; investigation, R.U.R.; resources, A.u.D.; data curation, A.u.D. and R.U.R.; writing-original draft preparation, A.u.D.; writing - review and editing, A.u.D. and S.; visualisation, M.H. and S.; supervision, H.E.-G. and M.J.; project administration, M.J. and M.H. The published version of the work has been reviewed and approved by all authors. All authors have read and agreed to the published version of the manuscript.

Funding: There was no outside support for this study.

Institutional Review Board Statement: All the research participants gave their informed consent for participation in this research before they participated in the study. The study abided by relevant Ethics Guide and ethical practices. Participants were protected from any emotional, physical, mental or any other forms of harm and were given the right to refuse to answer any question(s) if they wish to do so. In addition, the research participants' privacy were protected at all times.

Informed Consent Statement: Informed consent was obtained from all subjects involved in the study.

Data Availability Statement: Data may be acquired by sending an email to arif.hoti@gmail.com.

Conflicts of Interest: There are no conflict of interest declared by the authors.

\section{References}

1. Estrin, S.; Mickiewicz, T.; Stephan, U. Entrepreneurship, Social Capital, and Institutions: Social and Commercial Entrepreneurship across Nations. Entrep. Theory Pract. 2013, 37, 479-504. [CrossRef]

2. Ziegler, R.; Schulz, S.; Richter, L.; Schreck, M. Following Gandhi: Social Entrepreneurship as A Non-Violent Way of Communicating Sustainability Challenges. Sustainability 2014, 6, 1018-1036. [CrossRef]

3. Bansal, S.; Garg, I.; Sharma, G.D. Social Entrepreneurship as a Path for Social Change and Driver of Sustainable Development: A Systematic Review and Research Agenda. Sustainability 2019, 11, 1091. [CrossRef]

4. Daud-fhiri, N.S.; Ishak, S.I.D.; Abdullah, S.; Azmi, A.A.; Ishak, A.S.; Ahmad, Z. The Discussion of Social Entrepreneurship: Review of the Literature. In Proceedings of the MATEC Web of Conferences; EDP Sciences: Les Ulis, France, 2018; Volume 150, p. 05095. Available online: https:/ /www.sciencegate.app/document/10.1051/matecconf/201815005095 (accessed on 1 October 2021).

5. Huybrechts, B.; Nicholls, A. Social Entrepreneurship: Definitions, Drivers and Challenges. Soc. Entrep. Soc. Bus. 2012, 31-48. [CrossRef]

6. Blundel, R.K.; Lyon, F. Towards a 'Long View': Historical Perspectives on the Scaling and Replication of Social Ventures. J. Soc. Entrep. 2014, 6, 80-102. [CrossRef]

7. Mack, E.A. The Economics of Entrepreneurship; Parker, S.C., Ed.; Cambridge University Press: Cambridge, UK, 2018 ; p. 896. [CrossRef]

8. $\quad$ British Council. Social Enterprise Landscape in Pakistan; Social Enterprise: London, UK, 2015; pp. 1-60.

9. Asif, M.; Asghar, F.; Younis, A.; Mahmood, A.; Wang, L.Z. The Role of Social Entrepreneurship in Pakistan and its Impact on Economy. Int. J. Bus. Econ. Manag. 2018, 5, 117-127. [CrossRef]

10. Mathur, G.; Jugdev, K.; Fung, T.S. Project management assets and project management performance outcomes. Manag. Res. Rev. 2013, 36, 112-135. [CrossRef]

11. Mathur, G.; Jugdev, K.; Fung, T.S. Intangible project management assets as determinants of competitive advantage. Manag. Res. News 2007, 30, 460-475. [CrossRef]

12. Jugdev, K.; Mathur, G. Project management elements as strategic assets: Preliminary findings. Manag. Res. News 2006, 29 , 604-617. [CrossRef]

13. Nanthagopan, Y.; Williams, N.; Page, S. Understanding the nature of Project Management capacity in Sri Lankan nongovernmental organisations (NGOs): A Resource Based Perspective. Int. J. Proj. Manag. 2016, 34, 1608-1624. [CrossRef]

14. Rose, K.H.; Indelicato, G. Book Review: A Guide to the Project Management Body of Knowledge (PMBOK®Guide), Fourth Edition. Proj. Manag. J. 2009, 40, 104. [CrossRef]

15. Silvius, A.G.; Schipper, R.P. Sustainability in project management: A literature review and impact analysis. Soc. Bus. 2014, 4, 63-96. [CrossRef]

16. Huemann, M.; Silvius, G. Projects to create the future: Managing projects meets sustainable development. Int. J. Proj. Manag. 2017, 35, 1066-1070. [CrossRef]

17. Longoni, A.; Cagliano, R. Environmental and social sustainability priorities: Their integration in operations strategies. Int. J. Oper. Prod. Manag. 2015, 35, 216-245. [CrossRef] 
18. Shah, S.; Ganji, E.N.; Coutroubis, A. Evaluation of Sustainable Practices within Project Management Methods. In Proceedings of the MATEC Web of Conferences, Crete Island, Greece, 4 October 2017; EDP Sciences: Les Ulis, France, 2017; Volume 125, p. 2002. [CrossRef]

19. Tam, G. The program management process with sustainability considerations. J. Proj. Program Portf. Manag. 2010, 1, 17-27. [CrossRef]

20. Ebbesen, J.B.; Hope, A.J. Re-Imagining the Iron Triangle: Embedding Sustainability into Project Constraints. Proj. Manag. World J. 2013, 2. ISSN 2330-4480. Available online: http:/ / pmworldjournal.net/article/re-imagining-the-iron-triangle-embeddingsustainability-into-project-constraints / (accessed on 15 October 2021).

21. Haugan, G.T. Sustainable Program Management; Taylor \& Francis eBooks: New York, NY, USA, 2013. [CrossRef]

22. Silvius, G. Sustainability as a new school of thought in project management. J. Clean. Prod. 2017, 166, 1479-1493. [CrossRef]

23. Brones, F.; de Carvalho, M.M.; Zancul, E. Ecodesign in project management: A missing link for the integration of sustainability in product development? J. Clean. Prod. 2014, 80, 106-118. [CrossRef]

24. de Carvalho, M.M.; Junior, R.R. Impact of risk management on project performance: The importance of soft skills. Int. J. Prod. Res. 2014, 53, 321-340. [CrossRef]

25. Marcelino-Sádaba, S.; González-Jaen, L.F.; Pérez-Ezcurdia, A. Using project management as a way to sustainability. From a comprehensive review to a framework definition. J. Clean. Prod. 2015, 99, 1-16. [CrossRef]

26. Martens, M.L.; Carvalho, M.M. Sustainability and Success Variables in the Project Management Context: An Expert Panel. Proj. Manag. J. 2016, 47, 24-43. [CrossRef]

27. Di Domenico, M.; Haugh, H.; Tracey, P. Social Bricolage: Theorizing Social Value Creation in Social Enterprises. Entrep. Theory Pract. 2010, 34, 681-703. [CrossRef]

28. Huybrechts, B.; Nicholls, A. The role of legitimacy in social enterprise-corporate collaboration. Soc. Enterp. J. 2013, 9, 130-146. [CrossRef]

29. Moizer, J.; Tracey, P. Strategy making in social enterprise: The role of resource allocation and its effects on organizational sustainability. Syst. Res. Behav. Sci. 2010, 27, 252-266. [CrossRef]

30. Kwong, C.; Tasavori, M.; Cheung, C.W.-M. Bricolage, collaboration and mission drift in social enterprises. Entrep. Reg. Dev. 2017, 29, 609-638. [CrossRef]

31. Leadbeater, C. Social Enterprise and Social Innovation: Strategies for the Next Ten Years. A Social Enterprise Think Piece for the Office of the Third Sector. 2007. Available online: https:/ / community-wealth.org/sites/clone.community-wealth.org/files/ downloads/paper-leadbeater.pdf (accessed on 1 October 2021).

32. Dacin, P.A.; Dacin, M.T.; Matear, M. Social Entrepreneurship: Why We Don't Need a New Theory and How We Move Forward from Here. Acad. Manag. Perspect. 2010, 24, 37-57. [CrossRef]

33. De Bruin, A.; Shaw, E.; Lewis, K.V. The collaborative dynamic in social entrepreneurship. Entrep. Reg. Dev. 2017, 29, 575-585. [CrossRef]

34. Tam, G.C.K. Managing Project Sustainability: A Study of the Construction Industry in Hong Kong; London South Bank University: London, UK, 2018.

35. Ali, B.; Darko, E. Grants, Incubators and Innovation: A Snapshot of Social Enterprise Activity in Pakistan; Overseas Development Institute: London, UK, 2015.

36. Jugdev, K.; Mathur, G.; Fung, T.S. Project management assets and their relationship with the project management capability of the firm. Int. J. Proj. Manag. 2007, 25, 560-568. [CrossRef]

37. Thi, C.H.; Swierczek, F.W. Critical success factors in project management: Implication from Vietnam. Asia Pac. Bus. Rev. 2010, 16, 567-589. [CrossRef]

38. Jugdev, K. Through the Looking Glass: Examining Theory Development in Project Management with the Resource-Based View Lens. Proj. Manag. J. 2004, 35, 15-26. [CrossRef]

39. Barney, J.B.; Ketchen, D.J.; Wright, M. The Future of Resource-Based Theory. J. Manag. 2011, 37, 1299-1315. [CrossRef]

40. Crossan, M.M. The Knowledge-Creating Company: How Japanese Companies Create the Dynamics of Innovation. J. Int. Bus. Stud. 1996, 27, 196-201. [CrossRef]

41. Virtanen, I. In Search for a Theoretically Firmer Epistemological Foundation for the Relationship Between Tacit and Explicit Knowledge. Electron. J. Knowl. Manag. 2013, 11, 118-126.

42. Ekinge, R.; Lennartsson, B.; Taxén, L. Organizational Knowledge as a Basis for the Management of Development Projects. 2000. Available online: http:/ / urn.kb.se/ resolve?urn=urn:nbn:se:liu:diva-111359 (accessed on 1 August 2021).

43. Bueno, E.; Arrien, M.; Rodríguez, O. Modelo Intellectus: Medición y gestión del capital intellectual. Doc. Intellectus 2003, 5, 9-33.

44. Fernie, S.; Green, S.D.; Weller, S.J.; Newcombe, R. Knowledge sharing: Context, confusion and controversy. Int. J. Proj. Manag. 2003, 21, 177-187. [CrossRef]

45. Delak, B.; Damij, N. Knowledge Risk Assessments. In European Conference on Knowledge Management; Academic Conferences International Limited: Reading, UK, September 2015; p. 997. Available online: https:/ /www.proquest.com/openview/f8c901fc6 b2031d4af1160b90ae5e206/1?pq-origsite $=$ gscholar\&cbl=1796412 (accessed on 1 October 2021).

46. Nonaka, I. A Dynamic Theory of Organizational Knowledge Creation. Organ. Sci. 1994, 5, 14-37. [CrossRef]

47. Nonaka, I.; Takeuchi, H. The knowledge-creating company: How Japanese companies create the dynamics of innovation. Long Range Plan. 1996, 29, 592. [CrossRef] 
48. Silvius, G.; Schipper, R. A Conceptual Model for Exploring the Relationship Between Sustainability and Project Success. Procedia Comput. Sci. 2015, 64, 334-342. [CrossRef]

49. Aarseth, W.; Ahola, T.; Aaltonen, K.; Økland, A.; Andersen, B. Project sustainability strategies: A systematic literature review. Int. J. Proj. Manag. 2017, 35, 1071-1083. [CrossRef]

50. Akadiri, P.O. Understanding barriers affecting the selection of sustainable materials in building projects. J. Build. Eng. 2015 4, 86-93. [CrossRef]

51. Weninger, C.; Huemann, M. Project Initiation. In Banking, Finance, and Accounting; IGI Global: Hershey, PA, USA, 2014; Volume 1-3, pp. 1-17.

52. Eskerod, P.; Huemann, M. Sustainable development and project stakeholder management: What standards say. Int. J. Manag. Proj. Bus. 2013, 6, 36-50. [CrossRef]

53. Sanchez, M. Integrating sustainability issues into project management. J. Clean. Prod. 2015, 96, 319-330. [CrossRef]

54. Molenaar, K.R.; Sobin, N.; Antillón, E.I. A Synthesis of Best-Value Procurement Practices for Sustainable Design-Build Projects in the Public Sector. J. Green Build. 2010, 5, 148-157. [CrossRef]

55. Packendorff, J. Inquiring into the temporary organization: New directions for project management research. Scand. J. Manag. 1995, 11, 319-333. [CrossRef]

56. Shenhar, A.J.; Inst, S.; Dvir, D. Project Management Evolution: Past History and Future Research Directions. Innov. Proj. Manag. Res. 2004, 18, 57-64.

57. Söderlund, J. Building theories of project management: Past research, questions for the future. Int. J. Proj. Manag. 2004, 22, 183-191. [CrossRef]

58. Jugdev, K.; Mathur, G. Bridging situated learning theory to the resource-based view of project management. Int. J. Manag. Proj. Bus. 2013, 6, 633-653. [CrossRef]

59. Sandelowski, M.; Voils, C.I.; Barroso, J. Defining and Designing Mixed Research Synthesis Studies. Res. Sch. A Natl. Refereed J. Spons. Mid-South Educ. Res. Assoc. Univ. Ala. 2006, 13, 29.

60. Kay, A.; Roy, M.; Donaldson, C. Re-imagining social enterprise. Soc. Enterp. J. 2016, 12, 217-234. [CrossRef]

61. Weninger, C.; Huemann, M.; De Oliveira, J.C.; Filho, L.F.M.B.; Weitlaner, E. Experimenting with Project Stakeholder Analysis. In Global Approaches to Sustainability Through Learning and Education; IGI Global: Hershey, PA, USA, 2013 ; pp. 380-393.

62. Elkington, J. Partnerships from cannibals with forks: The triple bottom line of 21st-century business. Environ. Qual. Manag. 1998, 8, 37-51. [CrossRef]

63. Mswaka, W.; Armindo dos Santos de Sousa, T.; Cai, H.; Louws, M. Understanding social enterprises in the United Kingdom: The case of South Yorkshire. Eur. Bus. Rev. 2016, 28, 676-689. [CrossRef]

64. Shah, S.; Ganji, E.N. Sustainability adoption in project management practices within a social enterprise case. Manag. Environ. Qual. Int. J. 2019, 30, 346-367. [CrossRef]

65. Weerawardena, J.; McDonald, R.E.; Mort, G.S. Sustainability of nonprofit organizations: An empirical investigation. J. World Bus. 2010, 45, 346-356. [CrossRef]

66. Abdel-Raheem, M.; Ramsbottom, C. Factors Affecting Social Sustainability in Highway Projects in Missouri. Procedia Eng. 2016, 145, 548-555. [CrossRef]

67. Spangenberg, J.H. Economic sustainability of the economy: Concepts and indicators. Int. J. Sustain. Dev. 2005, 8, 47. [CrossRef]

68. Engwall, M.; Jerbrant, A. The resource allocation syndrome: The prime challenge of multi-project management? Int. J. Proj. Manag. 2003, 21, 403-409. [CrossRef]

69. Creswell, J.W.; Clark, V.L.P. Designing and Conducting Mixed Methods Research; SAGE Publications Ltd.: Thousand Oaks, CA, USA, 2017.

70. Bertaux, D.; Kohli, M. The life story approach: A continental view. Annu. Rev. Sociol. 1984, 10, 215-237. [CrossRef]

71. Eisenhardt, K.M. Building Theories from Case Study Research. Acad. Manag. Rev. 1989, 14, 532-550. [CrossRef]

72. Skocpol, T.; Somers, M. The Uses of Comparative History in Macrosocial Inquiry. Comp. Stud. Soc. Hist. 1980, 22, 174-197. [CrossRef]

73. Yin, R. How to do Better Case Studies: (With Illustrations from 20 Exemplary Case Studies). In The SAGE Handbook of Applied Social Research Methods; SAGE Publications, Ltd.: Thousand Oaks, CA, USA, 2014; pp. $254-282$.

74. Hair, J.F.; Sarstedt, M.; Hopkins, L.; Kuppelwieser, V. Partial least squares structural equation modeling (PLS-SEM). Eur. Bus. Rev. 2014, 26, 106-121. [CrossRef]

75. Jugdev, K.; Mathur, G. A Factor Analysis of Tangible and Intangible Project Management Assets; Project Management Institute: Newtown Square, PA, USA, 2006; Volume 7.

76. Bryson, J. What to do when stakeholders matter: Stakeholder identification and analysis techniques. Public Manag. Rev. 2004, 6, 21-53. [CrossRef]

77. Luthans, F.; Youssef, C.M. Human, Social, and Now Positive Psychological Capital Management: Investing in people for competitive advantage. Organ. Dyn. 2004, 33, 143-160. [CrossRef] 